\title{
MÛSZAKI FEJLESZTÉS ÉS INNOVÁCIÓ A GOMBATERMESZTÉSBEN
}

\section{TECHNOLOGY DEVELOPMENT AND INNOVATION IN MUSHROOM GROWING}

\author{
Almádi Bernadett ${ }^{1}$, Szilágyi Tibor Pál ${ }^{2}$, Rezsabek Tamás ${ }^{3}$ \\ ${ }^{1}$ Szent István Egyetem Gazdaság- és Társadalomtudományi Kar, Üzleti Tudományok \\ Intézete, Tevékenységmenedzsment és Logisztika Tanszék Cím: 2100, Magyarország, \\ Gödöllö, Páter Károly utca 1.; Telefon / Fax: +36-28-522-000, \\ bernadett.almadi@gmail.com \\ ${ }^{2}$ Szent István Egyetem, Gazdaság- és Társadalomtudományi Kar, Regionális és Vi- \\ dékfejlesztési Tanszék, H-2100, Magyarország, Gödöllö, Páter Károly utca 1.; Tele- \\ fon / Fax: +36-28-522000, sztp@stanford.edu \\ ${ }^{3}$ Szent István Egyetem Gépészmérnöki Kar, Müszaki Menedzsment Intézet, Alkalma- \\ zott Menedzsment Tanszék Cím: 2100, Magyarország, Gödöllö, Páter Károly utca \\ 1.; Telefon / Fax: +36-28-522-000,tamas.rezsabek@gmail.com
}

\begin{abstract}
The high intrinsic nutritional value of mushrooms is a cheap source of protein, from a nutritional point of view, it is becoming increasingly important. The importance of the sector is shown by the fact that it is mostly grown on horticultural, forestry, animal by-products and wastes so mushroom is the sector where sustainability can really be applicable. Characterized by a high degree of innovation it is a dynamically developing sector.
\end{abstract}

Keywords: technology development, innovation, mushroom growing, investment, labour safety

\section{Összefoglalás}

A gomba magas beltartalmi értékủ olcsó fehérje forrás, élelmezési szempontból egyre nagyobb jelentőséggel bír. Az ágazat jelentőségét alátámasztja, hogy többnyire kertészeti, erdészeti, állattenyésztési hulladékokon és melléktermékeken terem, így a gombatermesztés az az ágazat, amelyben igazán érvényesül a fenntarthatóság. Dinamikusan fejlődő ágazat révén nagyfokú innováció jellemzi.

Kulcsszavak: müszaki fejlesztés, innováció, gombatermesztés, beruházás, munkavédelem

\section{A téma aktualitása}

A gombák alacsony energiatartalmú, magas beltartalmi értékkel rendelkező táplálékai az emberiségnek.

A FAO adatai alapján a világ gombatermesztése évente 8 millió tonna, ennek mintegy $80 \%$-át a csiperkegomba, $15 \%$-át pedig a laskagomba teszi ki. Az Európai Unió legnagyobb gombatermesztő országa Lengyelország. Fejlődését a jelentős technológiai, ágazat szervezeti, logisztikai fejlesztésének köszönheti. 
Magyarországon 20-25 ezer tonna az éves termesztett gomba mennyisége. A 2014-2020-as időszakban ennek a mennyiségnek a legalább 50 ezer tonnára emelése a cél.

A gombavertikumban a célok között szerepel 60 gombatermesztő farm létesítése, 100 gombakomposzt hőkezelő alagút felépítése, 15 ezer tonna gombakonzerv előállítására alkalmas feldolgozói kapacitás létesítése.

Magyarországon az egy före eső fogyasztás 1,5 kg/fö/év körül alakul, lengyelországi csiperkegomba-fogyasztás 1,8 kg/fö/év, az Egyesült Királyságban 2,9 $\mathrm{kg} /$ fö/év, Spanyolországban 3,5 kg/fö/év [1].

\section{Szakirodalmi háttér}

Magyarország gombatermesztés terén 100 éves múltra tekint vissza. A két világháború között a világ harmadik legnagyobb gombatermelő országa volt.

A versenyképes gombatermesztés egyik feltétele a kedvező agrárökológiai feltételek megléte. Míg ezek a feltételek nem vagy csak nagy áldozatokkal valósíthatóak meg, addig a piaci, értékesítési, gazdasági viszonyok egy része viszonylag rövid időn belül megváltozhat. Ezek a változások többek között például beruházások, vásárlói szokások módosulása illetve termesztéstechnológiai innovációknak köszönhetően jöhetnek létre.

Az innováció fogalmát elöször 1911ben Joseph A.Schumpeter használta.

A müszaki fejlesztést Bublot közgazdasági oldalról közelíti meg, a technikai fejlődés legfőbb követelményeinek említi:

- az összes és a termelékenységre jutó költségek csökkentését,

- a változó ráfordítások nagyobb mennyiségben való alkalmazását

- a termelés növekedését. [2]

A müszaki fejlesztés az ezzel együtt járó látványos beruházási boom hozzájárul a termelékenység javulásához és a gazdasági növekedéshez.

$\mathrm{Az}$ információtechnológiai forradalom időszakában a müszaki fejlődés meghatározott iparágakban tökemegtakarító volt. [3]

Mindezek mellett a fogyasztói elvárásoknak való megfelelés áll a középpontban. A termékek és szolgáltatások versenyképességét meghatározó tényezők kapcsán egyenrangú tényezőkké léptek elő a logisztika és a minőség is [4]. Ez az élelmiszeripar két fontos eleme, mivel a gomba a "gyorsan romló” árucikkek közé tartozik.

A gazdálkodóknak olyan stratégiát szükséges alkalmazni, amely mellett képesek megfelelni az ökonómiai, ökológiai és társadalmi követelményeknek, ennek feltétele az innovatitás. [5]

A müszaki fejlesztés célja:

- A munka termelékenységének fokozása (önköltség csökkentése).

- A terméshozamok növelése.

- A munkafeltételek javítása.

- A lakossági fogyasztások minél magasabb szintü kiszolgálása.

- Választék bővítése.

- Minőség javítása. [6]

Mindezek mellett fontosnak tarjuk megjegyezni, Derek de Solla Price szavaival élve a „A tudományos munka nem lehet csupán önmagáért való." [7]

\section{Anyag és módszer}

Kutatásunk egy több lépcsős empirikus vizsgálattal zajlik jelenleg is. A kvalitatív technikák alkalmazása során félig struktúrát mélyinterjúkat alkalmaztunk. Célunk, hogy a gombatermesztés versenyképessége során feltárandó müszaki fejlesztésekhez vezető mélyebb összefüggéseket is megismerjük a szakemberek nézőpontjából. További célunk, hogy egy jövőbeni kvantitatív kutatást és azok hipotéziseit megalapozzuk. 


\section{Eredmények}

\subsection{Szaporítóanyag-előállítás}

A terméshozamok a kétspórás csiperke esetében elmaradnak az európai átlagtól, ennek növelése egyrészt fajták nemesítésével, másrészt termelési szerkezet optimalizációs vizsgálatokkal lehetséges, a termelés minden változóját vizsgálva.

$\mathrm{Az}$ un. spóramentes laska gombafajtának bevezetése a termesztésbe a munkafeltételek javulását eredményezné, mivel 1870 óta ismert, hogy bizonyos gombaspórák belégzése légzőszervi allergiás tüneteket idézhet elő. Ezen fajták a gombaágazatban dolgozó emberek egészségmegörzésében kulcsszerepet játszanak, ugyanis nem alakul ki a gombaspóra allergia. Ezen új fajtával a termesztőházak klímaberendezéseinek tisztításának gyakorisága is ritkulhat [8]. Automatizált blenderek bevezetésével hatékonyabb munkaerö - kihasználás jöhetne létre. Hátránya ennek a technológiának, hogy kisebb volumenü fajtakísérletekre nem ad lehetőséget.

A választék bővítéséhez Magyarországon kevésbé ismert gombafajoknak, pl.: mandulaillatú csiperkegomba (Agaricus blazei), ördögszekér laskagomba (Pleurotus eryngii), téli fülöke (Flammulina velutipes), pecsétviaszgomba (Ganoderma lucidum) és japán fagomba (Lentinula edodes) termesztésbe vonása lenne elsősorban ajánlott.

\subsection{Szubsztrátum előállítás és hőke- zelési módszerek}

A komposztkészítés jelentős szagemisszióval jár, emiatt sürgető fejlesztési cél a bunkeres komposztálás új, zárt rendszerü technológiájának kidolgozása. A bunkeres hőkezelők ,indoor” rendszerben müködnek. Az „,indoor” lényege, hogy minden folyamat, a komposztálás I., II. és III. fázisa teljesen zárt helyen történik. A keletkezett büzt, visszagyüjtik és ammóniamosó valamint biofilterek segítségével megtisztítják.

\subsection{Termesztés}

A magyar és európai piac is nagyobb mennyiségben igényelné a japán fagombát. Ehhez termesztéstechnológia fejlesztésekre lenne szükség.

A gombatermesztés, mint minden más ágazat törekszik az önköltségek csökkentésére. Az emelkedő energia árak mellett a társadalmi felelősségvállalást is szem előtt tartva, jelentős szerepet kapnak a gombatermesztésben is alkalmazható megújuló energiaforrások (termálvíz használat, biomasszaégetés, házak kifözése stb.)

A termesztés sok esetben még nem modern termesztő házakban történik, többek között légtechnikai, klímatechnikai fejlesztések szükségesek.

\section{Következtetések, javaslatok:}

- Törekedni kell a gomba export piacának növelésére.

- Meg kell ismertetni az emberekkel a gomba élettani hatásait a „Go Gomba/ Go Pink" kampány folytatásával.

- A gombatermesztés fejlődésének fontos és elengedhetetlen feltétele a gombatermesztésben tevékenykedők megfelelő szaktudásának megléte.

- A gomba fajtaválaszték bővítését elősegítendő, a hazai igényeket egy kérdőíves felméréssel tervezünk felmérni.

- Választék bővítése céljából megfontolandónak véljük olyan gombatermesztési technológiák felkutatását, tesztüzemben való kísérleteinek lefolytatását, melyeket hazánkban nem alkalmaznak pl.: kávézaccon történő gombatermesztés.

- A gomba vertikum ellátási lánc feltérképezése anomáliáinak feltárása céljából hozzájárulhat a gazdaságos gombatermesztéshez.

- Fontosnak tartjuk továbbá, hogy a csiperkegombát, minőségi osztályokba sorolják, beltartalmi értékei alapján.

- Végül, de nem utolsó sorban meg kell vizsgálni, hogy az új innovatív megoldá- 
soknak milyen gazdasági relevanciája van.

\section{Szakirodalmi hivatkozások}

[1] http://www.gombaforum.hu/2015/gazdasag/f riss-gombapiaci-statisztika/ Letöltve: 2015. február 7. 19.50

[2] Bublot $\mathrm{G},:$ A mezögazdasági termelés gazdaságtana Mezőgazdasági Kiadó, Budapest, 1987, 1 - 208 oldal

[3] Szalavetz A.: Müszaki fejlödés és tőkeintenzitás Közgazdasági Szemle, LIV. évf., 2007 február, 184 -198 oldal

[4] Gyenge, B., Kozma, T.: A logisztika és a minöség kapcsolata. In: Szücsné Szaniszló Zs. (szerk.) Nyertesek és vesztesek - az EUcsatlakozás 1,5 éves tapasztalatai. V. Regio- nális Tanácsadási Konferencia. Miskolc, 2005

[5] Takácsné György, K.: Innovációs formák, elterjedésük és szerepük a mezögazdaságban In: Ferencz Á (szerk.) Gazdálkodás és Menedzsment Tudományos Konferencia: Környezettudatos gazdálkodás és menedzsment. 1079 p. Konferencia helye, ideje: Kecskemét, Magyarország, 2013., 1060-1064 oldal

[6] Mohamed, Zs.: A mezögazdasági müszaki fejlesztés és kutatás hatásának mérése, Doktori (PhD) értekezés, Gödöllő, 2010, 13.oldal

[7] Derek de Solla Price: Kistudomány, nagytudomány, Budapest, Akadémiai Kiadó 1979

[8] Orosz M.: A hiperszenzitív pneumonitis (HP) (extrinzik allergiás alveolitis). Klinikai immunológia in. Pertányi Gy., Medicina Könyvkiadó Rt., Budapest, 2000. 